\title{
The Close Relationship Between Serious Human Rights Violations and Crimes Against Humanity: International Criminalization of Serious Abuses
}

\author{
La relación cercana entre violaciones serias de los \\ derechos humanos y crímenes de lesa humanidad: \\ criminalización internacional de serios abusos
}

\section{Juan Pablo Pérez-León Acevedo*}

\begin{abstract}
Summary: I. Introduction. II. Definition of Crimes Against Humanity and its Relationship with Serious Human Rights Violations. III. Relationship Between Serious Human Rights Violations and Crimes Against Humanity Under United Nations Legal Sources. IV. Relationship Between Serious Human Rights Violations and Crimes Against Humanity in the Practice of International and Hybrid Criminal Courts. V. Regional Human Rights Courts (Particularly the Inter-American Court of Human Rights) And International Criminal Courts. VI. Legal Consequences of the Qualification of Serious Human RightsViolations as Crimes Against Humanity. VII. Conclusions. VIII. Minimal Bibliography.
\end{abstract}

* Post-Doctoral Fellow at PluriCourts, Faculty of Law, University of Oslo (Norway). $\mathrm{PhD}$ in international law (Åbo Akademi University, Finland); LLM (Columbia University, USA); LLB (Pontifical Catholic University of Peru). He held post-doctoral positions at Åbo Akademi University (Institute for Human Rights), and University of Pretoria (Centre for Human Rights), South Africa. 
ABSTRACT: This article aims to evidence both the existence of a close relationship between the notions of serious human rights violations and crimes against humanity, and how this works in international law. To do so, international legal sources such as the United Nations practice, case-law of international and hybrid criminal courts and tribunals, and case-law of the Inter-American Court of Human Rights and other human rights bodies are taken into account. Thus, this article analyses how these and other international sources have examined the above-mentioned relationship, i.e., inter alia the similarities and differences between serious human rights abuses and the legal objective and subjective elements of crimes against humanity. Accordingly, it is found that, although some differences exist, the notion of serious human rights violations underlies the legal concept of crimes against humanity. In turn, this is linked to the relationship between those two categories of international law.

Key words: serious human rights violations, crimes against humanity, international criminal law, international human rights law.

RÉSUMÉ: Cet article vise à mettre en évidence l'existence d'une relation proche entre les notions de violations graves des droits de l'homme et de crimes contre l'humanité, et aussi comment cette relation fonctionne en droit international. Sources juridiques internationales comme la pratique des Nations Unies, la jurisprudence des tribunaux pénaux internationaux et hybrides et la jurisprudence de la Cour Interaméricaine des Droits de l'homme et des autres mécanismes internationaux de protection des droits de l'homme sont examinées. Ainsi, cet article analyse la façon dont celles-ci et d'autres sources internationales ont examiné la relation mentionnée ci-dessus, à savoir, entre autres, les similarités et les différences entre les violations graves des droits de l'homme et les éléments subjectifs et objectifs de crimes contre l'humanité. Alors, cet article trouve que, bien que quelques différences existent, la notion de violations graves des droits de l'homme sous-tend la notion juridique de crimes contre l'humanité. À son tour, cela est lié à la relation entre ces deux catégories de droit international.

Mots-clés: violations graves des droits de l'homme, crimes contre l'humanité, droit pénal international, droit international des droits de l'homme.

RESUMEN: Este artículo busca demostrar la existencia de una relación cercana entre las nociones de violaciones serias de derechos humanos y crímenes de lesa humanidad, y cómo tal relación opera en el derecho internacional. Fuentes jurídicas internacionales tales como la práctica de Naciones Unidas, jurisprudencia de cortes y tribunales penales internacionales e híbridos, y jurisprudencia de la Corte Interamericana de Derechos Humanos y de otros órganos internacionales de derechos humanos son examinadas. Por ende, este artículo analiza cómo estas y otras fuentes de derecho internacional han examinado la mencionada relación, es decir, entre otros, semejanzas y diferencias entre serios abusos de derechos humanos y los elementos objetivos y subjetivos de crímenes de lesa humanidad. Se concluye que la noción de violaciones serias de los derechos humanos subyace a la definición de crímenes de lesa humanidad. A su vez, ello se encuentra vinculado a la relación entre esas dos categorías de derecho internacional.

Palabras clave: violaciones serias de derechos humanos, crímenes de lesa humanidad, derecho penal internacional, derecho internacional de los derechos humanos. 


\section{INTRODUCTION}

Both legal and non-legal sources continuously report the commission of serious human rights violations and crimes against humanity perpetrated by state and non-state actors in situations of armed conflict or political unrest around the world. Due to the scale and pernicious effects of massive serious human rights violations, the international community has provided a series of answers. These answers have paid attention to how some of these serious human rights violations may constitute international crimes if the respective constitutive legal elements are present and a certain threshold of gravity is met. In turn, those answers have been provided across diverse international law realms: from drafting of international treaties and other instruments to setting up international courts. Also, these answers have been taken place at national, regional and international levels. This is no surprise as serious human rights violations and crimes against humanity are arguably one of the most important challenges that the international community faces. Besides that, the immense harm and sorrow inflicted on millions of victims around the world merits attention under not only international law but also other social sciences.

Against this background, a close connection between serious human rights violations and crimes against humanity can be observed. Accordingly, the main research questions in this piece are the following. The first research question is to determine whether and to want extent the notions of serious human rights violations and crimes against humanity are legally related to each other. The hypothesis here is to consider that there is an intrinsic relationship between the two categories under analysis based on consistent international practice. The second research question is to determine how this relationship works in international law. The hypothesis herein is to consider that serious human rights violations may be criminalized as crimes against humanity and, thus, are constitutive of crimes against humanity. In turn, crimes against humanity constitute a very important manifestation of serious human rights violations in international criminal law.

In addressing the main research questions and developing the hypotheses, the structure of this piece consists in five main parts, namely: i) definition of crimes against humanity and its relationship with serious human rights 
violations; ii) relationship between serious human rights violations and crimes against humanity under United Nations legal sources; iii) relationship between serious human rights violations and crimes against humanity in the practice of international and hybrid criminal courts; iv) regional human rights courts (particularly the Inter-American Court of Human Rights (IACtHR) and international criminal courts; and v) legal consequences of the qualification of serious human rights violations as crimes against humanity.

Prior to examining the legal arguments in the above-mentioned sections, attention should be drawn to the relationship between the concepts of crimes against humanity and ius cogens, i.e., imperative or generally accepted rules of international law. Whereas an international crime, including crimes against humanity, constitutes violations of ius cogens norms, i.e., violations of imperative international law norms not subject to derogation, not necessarily every violation of ius cogens results in the configuration of an international crime. ${ }^{1}$ Therefore, not every violation of human rights norms, which in some cases constitute ius cogens norms, is automatically and/or mechanically an international crime, ${ }^{2}$ particularly a crime against humanity. To qualify as such, the respective objective and subjective legal elements constitutive of those crimes must be proven. Related to this preliminary topic, in the well-known extradition case against the late ex-President of Chile, Augusto Pinochet, Lord Millet of the United Kingdom House of Lords (currently United Kingdom Supreme Court) concluded that:

...crimes prohibited by international law [crimes against humanity] attract universal jurisdiction under customary international law if two criteria are satisfied. First, they must be contrary to a peremptory norm of international law so as to infringe a jus cogens. Secondly, they must be so serious and on such a scale that they can justly be regarded as an attack on the international legal order. ${ }^{3}$

1 Remiro Brotóns, Antonio et al., Derecho internacional público, Madrid, Tecnos, 1997, p. 430 .

2 Ibidem. See also Schabas, William, An Introduction to the International Criminal Court, 2nd ed., Cambridge, Cambridge University Press, 2004, p. 34.

3 House of Lords (United Kingdom), Regina v. Bow Street Metropolitan Stipendiary Magistrate and Others, ex parte Pinochet Ugarte, Judgment, 24 March 1999, Opinion of Lord Millet. 
Esta revista forma parte del acervo de la Biblioteca Jurídica Virtual del Instituto de Investigaciones Jurídicas de la UNAM

\section{DEFINITION OF CRIMES AgAinst HUMANITY AND ITS RELATIONSHIP With SERIOUS HUMAN RightS ViOLATIONS}

\section{Defining Crimes Against Humanity}

It is necessary herein to refer to an operative definition of crimes against humanity. Thus, the definition of crimes against humanity under the International Criminal Court (ICC) Statute holds special importance arguably for three main reasons. ${ }^{4}$ First, it builds on both the instruments and case-law of the ICTY and the International Criminal Tribunal for Rwanda (ICTR) ${ }^{5}$ and has to an important extent been closely considered by hybrid criminal tribunals created after the ICC as well as in national criminal codes when domestically introducing crimes against humanity. Second, due to the high number of States Parties to the ICC Statute, this definition is arguably and at least to an important extent of a customary nature. Third, the ICC Statute has largely filled the gap left by the absence of a multilateral international treaty on crimes against humanity. ${ }^{6}$ In this regard, the international treaty regulation of crimes against humanity has followed a different approach than that of genocide, war crimes and torture insofar as specific international treaties have been adopted regarding these other categories of international crimes.

The notion itself of crimes against humanity, defined in detail under article 7 of the ICC Statute, has been construed through a long historical-legal process. Indeed, this process may be tracked down to the Statutes of and the seminal judgments rendered by the International Military Tribunals of Nüremberg and Tokyo, during the mid-XX century.

Bearing this in mind and under the ICC Statute, crimes against humanity correspond to serious criminal behaviors such as murder, extermination, torture or forced disappearance provided that these are "committed as part of a widespread or systematic attack directed against any civilian popula-

4 ICC Statute adopted on 17 July 1998.

5 ICTY Statute, article 5; ICTR Statute, article 3.

6 For much further discussion on this see: Sadat, Leila Nadya (ed.) Forging a Convention for Crimes against Humanity, Cambridge, Cambridge University Press, 2011. 
tion, with knowledge of the attack". ${ }^{7}$ Thus, if these legal elements are present and proven, the following acts constitute crimes against humanity:

(a) Murder;

(b) Extermination;

(c) Enslavement;

(d) Deportation or forcible transfer of population;

(e) Imprisonment or other severe deprivation of physical liberty in violation of fundamental rules of international law;

(f) Torture;

(g) Rape, sexual slavery, enforced prostitution, forced pregnancy, enforced sterilization, or any other form of sexual violence of comparable gravity;

(h) Persecution against any identifiable group or collectivity on political, racial, national, ethnic, cultural, religious, gender as defined in paragraph 3, or other grounds that are universally recognized as impermissible under international law, in connection with any act referred to in this paragraph or any crime within the jurisdiction of the Court;

(i) Enforced disappearance of persons;

(j) The crime of apartheid;

(k) Other inhumane acts of a similar character intentionally causing great suffering, or serious injury to body or to mental or physical health. ${ }^{8}$

According to this definition, crimes against humanity may be committed both during "peace time" and armed conflicts. Serious human rights violations constitute crimes against humanity provided that they present the following legal elements. Concerning objective or material elements: i) chapeaux (contextual) elements: widespread or systematic attack committed against a civilian population; and ii) underlying conducts: murder, extermination, torture, rape, persecution, etc. As to subjective or mental elements (mens rea): i) awareness of the contextual elements; and ii) mental element applicable to the specific underlying conduct. ${ }^{9}$

7 ICC Statute, article 7.1. See also ICC Statute, article 7.2.a (“Attack directed against any civilian population' means a course of conduct involving the multiple commission of acts referred to in paragraph 1 against any civilian population, pursuant to or in furtherance of a State or organizational policy to commit such attack;”).

8 ICC Statute, article 7.1.

9 For further discussion, see Schabas, William, The International Criminal Court. A Commen- 
Esta revista forma parte del acervo de la Biblioteca Jurídica Virtual del Instituto de Investigaciones Jurídicas de la UNAM

\section{Crimes Against Humanity and Serious Human Rights Violations}

International criminalization of serious human rights violations and, therefore, their qualification as crimes against humanity or, in general, international crimes (international criminal law) depends on the verification of the legal elements of crimes against humanity previously detailed.

Importantly, article 7.2.g of the ICC Statute (crime against humanity of persecution), provides for a specific reference to serious human rights violations as follows: "'Persecution' means the intentional and severe deprivation of fundamental rights contrary to international law by reason of the identity of the group or collectivity". Also, the text of the ICC Elements of Crimes includes an explicit reference to serious human rights violations when fleshing out the constitutive elements of the crime against humanity of persecution (article 7.1.h): "The perpetrator severely deprived, contrary to international law, one or more persons of fundamental rights".

The criminalization of serious human rights violations involves serious breaches of the so-called hard core human rights. An important feature of this group of human rights is that they cannot be derogated. ${ }^{10}$ Accordingly, it is possible to identify in this category of hard core human rights, fundamental human rights such as the right to be free from torture or other cruel, inhumane, or degrading treatment, the right to not be deprived of life in an extrajudicial or arbitrary manner, the right not to be subject to slavery or serfdom, and a set of fundamental fair trial guarantees. This list stems from provisions of major international and regional human rights treaties, namely, the International Covenant on Civil and Political Rights (article 4.2), the American Convention on Human Rights (article 27), and the European Convention for the Protection of Human Rights and Fundamental Freedoms (article 15.2). For example, case-law of the International Criminal Tribunal for the former Yugoslavia (ICTY) has examined this relationship

tary on the Rome Statute, Oxford, Oxford University Press, 2010, pp. 137 et seq; Cassese, Antonio, International Criminal Law, 1st ed., Oxford, Oxford University Press, 2003, 64 et seq.

10 See, for further discussion, Dupuy, Pierre-Marie, Droit International Public, Paris, Dalloz, 1998, pp. 206-210; and Carrillo Salcedo, Juan Antonio, Soberanía de los Estados y Derechos Humanos en Derecho Internacional Contemporáneo, 2nd ed., Madrid, Tecnos, 2001, pp. 106-107. 
when discussing some categories of crimes against humanity. ${ }^{11}$ As for international humanitarian law (IHL) treaties, article 3 common to the Four Geneva Conventions of 1949 is the paradigmatic example. Indeed, the European Court of Human Rights (ECtHR) has also referred to IHL treaties when examining serious human rights violations. ${ }^{12}$ All these instruments share in common that those rights shall be respected in all circumstances and, thus, are neither derogable nor subject to suspension. Accordingly, these provisions hold the status of ius cogens norms, ${ }^{13}$ and, therefore, bind all subjects of the international community, including states, individuals and international organizations.

The legal regulation of crimes against humanity under the ICC Statute is closely related to the notion of serious violations of human rights. As Theodor Meron, former President of the ICTY, pointed out, crimes against humanity "overlap with some violations of fundamental human rights (such torture, rape or enslavement), which thus become criminalized under a multilateral treaty", ${ }^{14}$ i. e., the ICC Statute.

Scholars have paid due attention to the relationship between serious human rights violations and individual criminal responsibility by considering the emergence of a norm on individual criminal responsibility for serious human rights violations. ${ }^{15}$ Moreover, such norm impacts on public international law fields and, therefore, cause diverse changes in the dynamic and evolving international law structure. ${ }^{16}$

Therefore, crimes against humanity and serious human rights violations are two notions which are intertwined. Indeed, the latter is arguably the central defining element of crimes against humanity.

11 E.g., Prosecutor v. Karadzić, IT-95-5/18, Judgment, Trial Chamber, 24 March 2016, para. 504.

12 ECtHR, Marguš v. Croatia, application no. 4455/10, 27 May 2014, para. 132.

13 See, inter alia, Novak, Fabián and Salmón, Elizabeth, Las Obligaciones Internacionales del Perú en Materia de Derechos Humanos, Lima, Fondo Editorial de la Pontificia Universidad Católica del Perú/IDEI, 2002, p. 85.

14 Meron, Theodor, "International Law in the Age of Human Rights-General Course on Public International Law”, in Recueil Générale de Cours de la Académie de Droit International, volume 301, 2003, p. 165.

15 E.g., Sunga, Lyal, Individual responsibility in international law for serious human rights violations, Amsterdam, Martinus Nijhoff, 1992, p. 157.

16 Idem. 
Esta revista forma parte del acervo de la Biblioteca Jurídica Virtual del Instituto de Investigaciones Jurídicas de la UNAM

\section{Similarities and Differences}

This sub-section endeavours to discuss some important similarities and differences between the notion of "serious human rights violations" and the legal definition of "crimes against humanity". Concerning similarities, the following may be mentioned. First, serious human rights violations and crimes against humanity constitute mainly grave breaches of the same set of core human rights which are protected by international instruments and other legal sources. Thus, both serious human rights violations and crimes against humanity may be portrayed as extremely pernicious attacks against very basic human rights such as the rights to: life, physical and bodily integrity, freedom from slavery, minimum fair trial guarantees, etc.

Second, both serious human rights violations and crimes against humanity constitute violations of ius cogens norms and/ or similar international customary rules and principles. ${ }^{17}$ This corresponds to the fact that the heinous acts underlying both serious human rights violations and crimes against humanity shock the very foundational values shared by the international community considered as a whole. Moreover, the commission of either serious human rights violations or crimes against humanity poses a serious threat to peace and international security.

Third, the qualification of a particular set of facts as serious human rights violations and/or crimes against humanity normally leads to similar legal consequences. ${ }^{18}$ Thus, serious human rights violations, which may in turn constitute crimes against humanity, genocide and war crimes, trigger the non-application of amnesties and statute of limitations as well as the use of universal and international jurisdictions. In turn, by definition, a criminal act or a series of criminal acts that are crimes against humanity prompt similar legal effects.

Fourth, the prohibition of serious human rights violations and crimes against humanity imposes obligations on the totality of legal subjects of the international community. Thus, for example, States are obliged not to incur in practices of serious human rights violations and crimes against humanity

17 See inter alia Remiro Brotóns, Antonio et al., op. cit., p. 430; and Schabas, William, An Introduction..., cit., p. 34.

18 For further discussion see infra section VI. 
as much as individuals are expected not to carry out these atrocities. Concerning either serious human rights violations or crimes against humanity, erga omnes obligations follow.

With regard to differences between the notions/concepts of serious human rights violations and crimes against humanity, the following may be mentioned. First, "serious human rights violations" is a broader concept than crimes against humanity. Indeed, considering their respective material scope, it could be argued that crimes against humanity is a species of the more comprehensive "serious human rights violations" notion. Serious human rights violations may be considered as an umbrella concept which also includes other categories of international crimes such as genocide, i.e., when serious human rights violations are perpetrated with the intent to partially or totally destroy any of the protected groups-national ethnic, racial or religious groups-and war crimes, i.e., serious human rights violations committed in and in connection with national or international armed conflicts. ${ }^{19}$

Second, when it comes to serious human rights violations, one single act even if not committed systematically may fall into that category. For example, the commission of an isolated and single act of torture constitutes a serious human rights violation. Conversely, to constitute crimes against humanity, serious human rights violations must be committed in a systematic or widespread pattern.

Third, whereas crimes against humanity imply the determination of individual criminal liability, serious human rights violations may be related to both state and individual accountability. As discussed later, ${ }^{20}$ this is mirrored in the respective competent international and regional courts. Thus, while individual criminal liability for crimes against humanity is determined by international, hybrid and criminal national courts, international state responsibility for serious human rights violations falls under the mandate of regional human rights courts and the International Court of Justice.

Fourth, the legal analytical structure of crimes against humanity, as also applied by national and international courts, reflects long-standing categories and methodology of criminal law. Thus, crimes against humanity are

19 See for definitions of international crimes, inter alia, ICC Statute articles 6 (genocide), 7 (crimes against humanity) and 8 (war crimes).

20 See infra sections IV and V. 
broken down in elements which belong either to actus reus (objective elements) and mens rea (subjective elements). ${ }^{21}$ Conversely, when the notion of serious human rights violations is invoked or used, the analysis is not conducted under or just confined to those definitional elements.

All in all, the similarities and differences between serious human rights violations and crimes against humanity previously examined constitute clear evidence of the intense relationship between the two categories under analysis.

\section{RELATIONSHIP BETWEEN SERIOUS HUMAN RigHTS VIOLATIONS and Crimes Against Humanity under United Nations Legal SOURCES}

\section{International Law Commission (ILC)}

The ILC has largely examined the topic under analysis in its Draft Code of Crimes against the Peace and Security of Humankind. The ILC has considered serious human rights violations as intrinsically constitutive of crimes against humanity. In 1984, as part of the elaboration of the Draft Code of International Crimes against the Peace and Security of Humankind, Thiam further examined such relationship and concluded that: i) once reached certain gravity, serious human rights violations constitute international crimes, particularly crimes against humanity; ii) there is a difference in degree rather than nature between serious human rights violations and crimes against humanity; and iii) once certain threshold of seriousness is met both categories "se confondent". ${ }^{22}$ In 1986, crimes against humanity were study deeply. ${ }^{23}$ In the 1991 version of the Draft Code of Crimes against the Peace and Security of Humankind, the expression "crimes against humanity" was replaced with "systematic or mass violations of human rights" as a crime against peace and security of humankind, and under this category the fol-

21 Cassese, Antonio, op. cit., pp. 74-82.

22 Second report on the draft code of offences against the peace and security of mankind, by Mr. Doudou Thiam, UN Doc. A/CN.4/377, 1 February 1984, para. 40.

23 Report of the ILC on the work of its thirty-eight session, 5 May-11 July 1986, UN Doc. A/41/10, pp. 43-46. 
Esta revista forma parte del acervo de la Biblioteca Jurídica Virtual del Instituto de Investigaciones Jurídicas de la UNAM

lowing grave violations were included: i) murder; ii) torture; iii) slavery, servitude or forced labour; iv) persecution; and $v$ ) deportation or forcible transfer of population. ${ }^{24}$

Later, in 1996, the ILC replaced "systematic or mass violations of human rights" with "crimes against humanity" providing a more comprehensive definition of this category: "A crime against humanity means any of the following acts, when committed in a systematic manner or on a grand large scale and instigated or directed by a Government or by any organization or group.... ${ }^{25}$ In turn, the underlying conducts are: i) murder; ii) extermination; iii) torture; iv) enslavement; v) persecution; vi) institutionalized discrimination on racial, ethnic or religious grounds seriously affecting basic human rights; vii) arbitrary deportation or forcible transfer of population; viii) arbitrary imprisonment; ix) forced disappearance; $x$ ) rape and other sexual crimes; and $x i$ ) other inhumane acts. ${ }^{26}$

The change in terminology had no substantial impact on the legal concept under the said article. This is because the 1996 draft provision basically incorporated the same crimes and elements than those already contained in the 1991 draft provision. The very ILC in its 1994 Draft Statute for an International Criminal Court referred to "serious human rights violations" (1991 draft provision) when commenting on the category of crimes against humanity. ${ }^{27}$ Thus, the notions or concepts of widespread or systematic human rights violations and crimes against humanity converge. Moreover, crimes against humanity may take place in peace time and, as a discrete international crime, requires no link with international or internal armed conflicts-unlike war crimes and, therefore, crimes against humanity must be prosecuted whenever committed (war and peace time).

24 Report of the International Law Commission on the work of its forty-second session, 1991 ILC Report (A/46/10), Draft Code of Crimes against the Peace and Security of Humankind (1991), article 21. Systematic or mass violations of human rights.

25 Report of the International Law Commission on the work of its forty-seventh session, 1996 ILC Report (A/51/10), Draft Code of Crimes against the Peace and Security of Humankind (1996), article 18. Crimes against humanity.

26 Idem.

27 Report of the International Law Commission on the work of its forty-sixth session, 1994 ILC Report (A/48/31), Draft Statute for an International Criminal Court, article 20.d, p. 40 . 
Esta revista forma parte del acervo de la Biblioteca Jurídica Virtual del Instituto de Investigaciones Jurídicas de la UNAM

\section{United Nations Security Council}

UN Security Council Resolutions adopted under Chapter VII of the UN Charter have referred to serious violations of IHL, i.e., human rights in the context of armed conflicts, and international human rights law as threats to international peace and security. Three concrete examples, related to the work of international criminal tribunals/courts with competence over inter alia crimes against humanity, are mentioned herein in order to illustrate this point.

The first two examples correspond to the UN Security Council Resolutions adopted under Chapter VII and based upon which the ICTY and the ICTR, with competence over inter alia crimes against humanity, were established as measures to restore and/or preserve international peace and security. Thus, concerning Security Resolution 827 (1993) which constituted the ICTY, the Security Council provided the following general considerations that underlie the relationship between serious human rights violations and international crimes, i.e., including crimes against humanity:

Expressing once again its grave alarm at continuing reports of widespread and flagrant violations of international humanitarian law occurring within the territory of the formerYugoslavia, and especially in the Republic of Bosnia and Herzegovina, including reports of mass killings, massive, organized and systematic detention and rape of women, and the continuance of the practice of "ethnic cleansing", including for the acquisition and the holding of territory.

Determining that this situation continues to constitute a threat to international peace and security.

Convinced that in the particular circumstances of the former Yugoslavia the establishment as an ad hoc measure by the Council of an international tribunal and the prosecution of persons responsible for serious violations of international humanitarian law would enable this aim to be achieved and would contribute to the restoration and maintenance of peace. ${ }^{28}$

Security Council Resolution 955 (1994) by which the Security Council set up the ICTR contains similar grounds for the creation of the ICTR:

28 UN Doc. S/RES/827 (1993), 25 May 1993, Preamble. 
Expressing once again its grave concern at the reports indicating that genocide and other systematic, widespread and flagrant violations of international humanitarian law have been committed in Rwanda,

Believing that the establishment of an international tribunal for the prosecution of persons responsible for genocide and the other above-mentioned violations of international humanitarian law will contribute to ensuring that such violations are halted and effectively redressed. ${ }^{29}$

The third example comes from one of the two situations referred to by the Security Council (Darfur and Libya), in exercise of its Chapter VII powers and according to article 13.b of the ICC Statute, to the ICC. Thus, in the referral of the situation of Darfur, Sudan for investigation to the ICC, Security Council Resolution 1593 (2005) once again evidenced the relationship between serious human rights violations and international crimes, including crimes against humanity, in the Security Council's practice:

Taking note of the report of the International Commission of Inquiry on violations of international humanitarian law and human rights law in Darfur (S/2005/60),

4. Also encourages the Court, as appropriate and in accordance with the Rome Statute, to support international cooperation with domestic efforts to promote the rule of law, protect human rights and combat impunity in Darfur; ${ }^{30}$

\section{Former Sub-Commission on the Prevention and Discrimination} and the Protection of Minorities

The relationship between serious human rights violations and crimes against humanity was in a pioneer manner examined by the extinct Human Rights Commission, especially the former Sub-Commission on the Prevention of Discrimination and the Protection of Minorities (the Sub-Commission). This body suggested that enforced disappearance may be a crime against humanity, and invoked the relationship between widespread or systematic human rights violations and crimes against humanity. ${ }^{31}$ Thus, it proposed

29 UN Doc. S/RES/955 (1994), 8 November 1994, Preamble.

30 UN Doc. S/RES/1593 (2005), 31 March 2005.

31 Resolution 1982/11. 
the UN General Assembly, when inviting the ILC to draft the Code of Crimes against the Peace and Security of Humankind, to recommend to consider those violations and the Sub-Commission's observations. ${ }^{32}$ A study on amnesty laws considered in which circumstances serious human rights violations may configure crimes against humanity. ${ }^{33}$

The Sub-Commission considered widespread or systematic human rights violations perpetrated under orders issued or consented by state authorities as international crimes. The Sub-Commission arguably sought to establish both international state responsibility and individual criminal responsibility, which reflected the willingness to enhance the international legal foundations in the domain of human rights and, particularly to strengthen the fight against serious human rights violations. ${ }^{34}$ Individual criminal responsibility is not exclusive to state agents as it also applies to any individual responsible for international crimes.

The Sub-Commission drafted and submitted for consideration of the UN General Assembly a declaration on the recognition of gross and massive violations of human rights perpetrated on the orders of governments or sanctioned by them as an international crime. Flagrant or massive human rights violations committed under governmental orders or with their acquiescence were considered a serious violations of the obligation to respect human rights and constituted international crimes, particularly crimes against humanity. Article 3 of this draft declaration also stated that: "States whose Governments perpetrated gross and massive violations of human rights or whose Governments sanctioned them are responsible under international law for such violations as for an international crime". ${ }^{35}$

Thus, a link between flagrant or massive human rights violations, the principle of/obligation to respect human rights, and individual criminal responsibility may be identified. The international norm which triggers international (criminal) individual liability has an impact on the principle of

32 See UN Doc. E/CN.4/Sub.2/1982/15, paras. 3, 4 y 92.

33 Special Rapporteur Joinnet, UN Doc. E/CN.4/Sub.2/1985/16, paras. 66-76. See also UN Doc. E/CN.4/Sub.2/1993/19.

34 See Expanded Working Paper on the Recognition of Gross and Massive Violations of Human Rights Perpetrated on the Orders of Governments or Sanctioned by them as an International Crime, UN Doc. E/CN.4/Sub.2/1997/29, 28 May 1997.

35 Idem. 
Esta revista forma parte del acervo de la Biblioteca Jurídica Virtual del Instituto de Investigaciones Jurídicas de la UNAM

respect for fundamental rights. ${ }^{36}$ All of this reflects an increasing interaction between international human rights law and international criminal law.

\section{Overall Assessment}

From the manner in which the practice of the UN organs examined in this section has dealt with the relationship between serious human rights violations and crimes against humanity, the following may be noted.

First, the UN organs, particularly, the former Human Rights Commission and the Security Council considered in this chapter have used a broad terminology to encompass grave atrocities committed across the world. Thus, expressions similar to serious human rights violations have continuously been used to refer to events constitutive of international crimes, crimes against humanity included. This trend has also been present at the regional level. For example, article 4(h) of the Constitutive Act of the African Union considers under the umbrella concept of "grave circumstances": war crimes, genocide and crimes against humanity.

Second, due to its more technical mandate, the ILC has provided a higher level of legal accuracy by identifying legal elements of crimes against humanity within the larger universe of serious human rights violations. This proved to be quite useful when a new generation of international/hybrid criminal courts started functioning since the early nineties. Indeed, the work on definition of crimes against humanity at the ILC was an important legal source when the definition of crimes against humanity under the ICC Statute was negotiated and drafted. ${ }^{37}$

Third, certain complementarity in approaching the relationship between the notion of serious human rights violations and the legal definition of crimes against humanity across UN organs is accordingly found. Thus, whereas the former Human Rights Commission and the Security Council have mainly remained at a more general level, the ILC arrived to a much more specific level of analysis by crafting the legal configuration of crimes

36 Abellán, Victoria, "La responsabilité internationale de l'individu”, in Recueil des Cours de la Académie de Droit International, t. 280, 1999, p. 272.

37 For further discussion see: Schabas, William, The International Criminal..., cit, pp. 140141. 
against humanity. In any event, both types of approaches have converged to make it clear the close relationship between the two categories under analysis.

\section{Relationship Between Serious Human Rights Violations and CRimes Against Humanity in the Practice of InTERnational AND HYBRID CRIMINAL COURTS}

\section{Case-Law of International and Hybrid Criminal Tribunals other than the International Criminal Court}

The ICTY, which has mandate to determine individual criminal responsibility for international crimes that took place in the former Yugoslavia during the 1990's Balkan wars, in Kupreskic highlighted the relationship between the two notions under consideration when referring to "other inhumane acts" as crimes against humanity:

..."other inhumane acts" can instead be identified in international standards on human rights such as those laid down in the Universal Declaration on Human Rights of 1948 and the two United Nations Conventions on Human Rights of 1966. Drawing upon the various provisions of these texts, it is possible to identify asset of basic rights appertaining to human beings, the infringement of which may amount, depending on the accompanying circumstances, to a crime against humanity. ${ }^{38}$

The case-law of the ICTY has consistently examined the relationship between serious human rights violations and their criminalization as crimes against humanity. Thus, in Karadzić, the crime against humanity of cruel and/or inhumane treatment was related to the prohibition under customary international and human rights treaties. ${ }^{39}$ Concerning persecution as crime against humanity, in inter alia, the Trial Chambers in Karadzić and

38 Prosecutor v. Kupreskic, IT-95-16-T, Judgment, Trial Chamber, 14 January 2000, para. 563.

39 Prosecutor v. Karadzić, IT-95-5/18, Judgment, Trial Chamber, 24 March 2016, para. 504. 
Esta revista forma parte del acervo de la Biblioteca Jurídica Virtual del Instituto de Investigaciones Jurídicas de la UNAM

Stakić held that conducts which violate fundamental human rights under customary or treaty international law may constitute persecution..$^{40}$ Also, in Krnojelac, the Trial Chamber found that there is no additional or separate requirement of a gross or blatant denial of a fundamental human right since it is sufficient that a persecutory act or omission possesses the required level of seriousness or gravity as other crimes against humanity. ${ }^{41}$ Nevertheless, this same Chamber concluded that solely "gross or blatant denial of fundamental human rights" would meet the gravity test required to qualify as crime against humanity. ${ }^{42}$

Commission of crimes against humanity represents an extremely heinous action, which fully merits its punishment regardless of the nature of armed conflict. This in turn underlies the obligation to prosecute even through universal jurisdiction. ${ }^{43}$ In Tadic, the ICTY reflected this logics grounded in the existence of customary international law under which no connection between crimes against humanity and an armed conflict is required. ${ }^{44}$

The Extraordinary Chambers in the Courts of Cambodia (ECCC) with mandate to investigate and prosecute international (and serious domestic) crimes committed by the leadership of the Khmer Rouge regime between 1975 and 1979 has also addressed the relationship between serious human rights violations and crimes against humanity. Concerning persecution as a crime against humanity, the ECCC Supreme Court Chamber in Case 001 concluded that persecutory acts as such do not need to constitute international crimes but "must result in breaches of fundamental human rights under treaty or customary international law in order to rise to the requisite level of gravity and severity". ${ }^{45}$ Thus, persecutory acts rise to the level of gravity or seriousness of other underlying crimes against humanity, which

40 Prosecutor v. Karadzić, IT-95-5/18, Judgment, Trial Chamber, 24 March 2016, para. 499; Prosecutor v. Stakić, IT-97-24, Judgment, Trial Chamber, 31 July 2003, para. 773.

41 Prosecutor v. Krnojelac, IT-97-25, Judgment, Trial Chamber, 15 March 2002, para. 434, fn. 1303.

42 Ibidem, para. 434.

43 See Ambos, Kai, El nuevo derecho penal internacional, Lima, ARA Editores, 2004, p. 97.

44 Prosecutor v. Tadic, IT-94-1-T, Decision on the Defence Motion for Interlocutory Appeal on Jurisdiction, Judgment, Appeals Chamber, 2 October 1995, para. 141. See also Meron, Theodor, "War Crimes Law Comes of Age", American Journal of International Law, vol. 92, n. 3, 1998, pp. 464-466.

45 Case 001, Appeal Judgment, Supreme Court Chamber, 3 February 2012, para. 261. 
results in breaches of fundamental human rights. This ratio decidendi has been considered in later decisions, e.g., the ECCC Trial Chamber judgment in Case 002/01. ${ }^{46}$

\section{Practice of the International Criminal Court}

Concerning the practice of the ICC, the ICC Pre-Trial Chamber in its decision on confirmation of charges in Katanga and Ngudjolo Chui considered that sexual slavery as a crime against humanity involves violations of the peremptory norm which prohibits slavery. ${ }^{47}$ In turn, this prohibition had long before been recognized in international human rights treaties and not subject to suspension or derogation under any circumstances. Sexual slavery involves serious violations of inter alia the victims' freedom of movement and power to decide on matters corresponding to his/her sexual activity. ${ }^{48}$ Also, in examining the application of the principle of legality or nullum crimen sine lege (article 22 of the ICC Statute), the Chamber in Katanga and Ngudjolo Chui importantly concluded that inhumane acts as crimes against humanity (article 7.1.k of the ICC Statute) are:

...considered as serious violations of international customary law and the basic rights pertaining to human beings, drawn from the norms of international human rights law, which are of a similar nature and gravity to the acts referred to in article 7(1) of the Statute. ${ }^{49}$

To constitute crimes against humanity, facts which are generally speaking labelled as serious human rights violations shall meet the subjective and objective elements of those crimes. Thus, the ICC Pre-Trial Chamber, examined not only the general or contextual legal elements of crimes against humanity but also specific legal elements of, in this particular case, "other inhumane acts”, namely, requirements of great suffering or serious injury to

46 Case 002/01, Judgment, Trial Chamber, 7 August 2014, para. 432.

47 Prosecutor v. Katanga and Ngudjolo Chui, ICC-01/04-01/07-717, Decision on the confirmation of charges, Pre-Trial Chamber, 30 September 2008, para. 431.

48 Ibidem, para. 432.

49 Ibidem, para. 448. 
Esta revista forma parte del acervo de la Biblioteca Jurídica Virtual del Instituto de Investigaciones Jurídicas de la UNAM

body, mental or physical health, which corresponds to the ICC Statute and the text of the ICC Elements of Crimes. ${ }^{50}$

In the same decision, Judge Anita Usacka, in her partly dissenting opinion, further analyzed "other inhumane act" and arrived to the conclusion whereby this provision is flexible enough to "cover serious violations of human rights not specifically enumerated" provided that those "inhumane acts" are of seriousness or gravity comparable to the other crimes listed in article 7.1 of the ICC Statute. ${ }^{51}$

The approach adopted by the ICC Pre-Trial Chamber reflects, on the one hand, the nature of crimes against humanity as criminalization of serious human rights violations, and, on the other hand, the need for meeting the subjective and objective elements constitutive of crimes against humanity. Thus, the delicate balance between international criminal law and international human rights law concerning substantive international law is arguably well-kept. Likewise, the International Commission of Investigation on Darfur (Sudan) in examining the facts and applicable legal framework in this region, which led to opening an investigation and related cases before the ICC, pointed out that serious human rights violations may constitute crimes against humanity provided that the (objective and subjective) legal elements of the latter are present, especially their systematic or widespread character. ${ }^{52}$ Moreover, international human rights treaties such as the Convention on the Rights of the Child have been considered by the ICC when deciding on cases involving international crimes under its jurisdiction. ${ }^{53}$

At the procedural level, particularly, evidentiary rules, the relationship between the notion of serious human rights violations and the legal definition of crimes against humanity has been present in the emerging case-law of the ICC. Thus, in the second verdict judgment rendered by the ICC, the Trial Chamber in Ngudjolo Chui correctly reminded that an investigation into serious human rights violations is not identical to a criminal investigation. This is because reports on the existence of serious human rights viola-

\footnotetext{
50 Ibidem, paras. 449-454.

51 Ibidem, Partly Dissenting Opinion of Tudge Anita Usacka, para. 31.

52 International Commission of Inquiry on Darfur, Report of the International Commission of Inquiry on Darfur to the United Nations Secretary-General, Pursuant to Security Council Resolution 1564 of 18 September 2004, 25 January 2005, para. 637.

53 Prosecutor v. Bemba Gombo, ICC-01/05-01/08-3343, Judgment pursuant to article 74 of the Statute, Trial Chamber, 21 March 2016, para. 70.
} 
tions are elaborated on a non-adversarial basis, fundamentally grounded in oral testimony (even stemming from hearsay evidence), and there is always redaction of the identity of the sources, all of which differs from the manner in which criminal investigations are conducted. ${ }^{54}$ Thus, excerpts from the report on serious human rights violations mentioned in the judgment were beforehand corroborated..$^{55}$ In the third ICC trial judgment, the Trial Chamber in Katanga followed the same approach. ${ }^{56}$ Once again, the Chamber recalled that a report on an investigation of serious human rights violations is not subject to the same criteria as those applicable to a criminal investigation as reports "are prepared in a non-adversarial manner; they are essentially based on oral testimony, sometimes derived from hearsay, and the identity of the sources is always redacted". ${ }^{57}$

In Lubanga, when legally examining the international crimes perpetrated by the accused, the Trial Chamber made an explicit reference to the context in which they took place, i.e., widespread serious human rights violations. ${ }^{58}$ Indeed, as recalled by the Trial Chamber and in accordance with article 21(3) of the ICC Statute and previous-case law of the ICC Appeals Chamber, the interpretation of the ICC Statute and the exercise of the ICC jurisdiction must be subject to international human rights law. ${ }^{59}$ Moreover, one of the complementary legal sources to be applied by the ICC is international human rights law. Therefore, when interpreting and applying article 7 of the ICC Statute, the ICC should and, actually, has considered international human rights law sources. Bearing in mind the quasi-universal scope of the ICC, it is important that the ICC, when interpreting the legal elements of crimes against humanity, considers the notion of "serious human rights violations" as developed in human rights law sources. This clearly has to be conducted within the limits of the ICC's mandate. Thus, analysis of facts under the statutory definition of crimes against humanity,

54 Prosecutor v. Ngudjolo Chui, ICC-01/04-02/12-3-tENG, Judgment pursuant to article 74 of the Statute, Trial Chamber, 18 December 2012, para. 294.

55 Ibidem, para. 296.

56 Prosecutor v. Katanga, ICC-01/04-01/07-3436-tENG, Judgment pursuant to article 74 of the Statute, Trial Chamber, 7 March 2014, paras. 326-327.

57 Ibidem, para. 326.

58 Prosecutor v. Lubanga, ICC-01/04-01/06-2842, Judgment Pursuant to Article 74 of the Statute, Trial Chamber I, 14 March 2012, para 911.

59 Ibidem, para. 602. 
which reflects to an important extent existing customary international law, is expected to be appropriately enriched by the notion of "serious human rights violations" which albeit not identical to "crimes against humanity" is intrinsically related to it.

In the ICC's practice, the ICC's case-law on reparations and victims' participation have particularly paid close attention to human rights jurisprudence related to serious human rights violations. Thus, for example, the ICC in its first reparations decision in Lubanga noted that:

...given the substantial contribution by regional human rights bodies in furthering the right of individuals to an effective remedy and to reparations, the Chamber has taken into account the jurisprudence of the regional human rights courts and the national and international mechanisms and practices that have been developed in this field. ${ }^{60}$

The ICC Trial Chamber importantly clarified that although the IACtHR (and also the ECtHR) can order reparations against States rather than individuals, general concepts underlying reparations stemming from the caselaw of those bodies may be useful to the ICC ${ }^{61} \mathrm{Also}$, in examining reparations to redress harm caused by the commission of international crimes, the Chamber correctly pointed to "a growing recognition in international human rights law that victims and groups of victims may apply for and receive reparations". ${ }^{62}$ The underlying reason for this jurisprudential crossfertilization is that the type of atrocities inflicting harm on victims at the ICC and the IACtHR essentially corresponds to the intrinsically related meaning and scope of crimes against humanity and serious human rights violations.

When the ICC Appeals Chamber has used the case-law of the IACtHR and ECtHR to interpret the ICC Statute and other ICC legal framework instruments, it has highlighted the difference in mandates between the ICC and regional human rights courts, i. e., the latter deal with State responsibility for violations of human rights guaranteed in the respective human

60 Prosecutor v. Lubanga, ICC-01/04-01/06-2904, Decision establishing the principles and procedures to be applied to reparations, Trial Chamber, 7 August 2012, para. 186.

61 Ibidem, footnote 377.

62 Ibidem, para. 217. 
rights instruments. ${ }^{63}$ In any event, the ICC has explicitly made reference to serious human rights violations when, e.g., interpreting and better delimiting the reparations regime for international crimes (including crimes against humanity) under the ICC's jurisdiction: "The Appeals Chamber also notes that, as pointed out by the Trust Fund, other human rights courts, such as the IACtHR, have ordered reparations on a collective basis when dealing with mass crimes and mass victimization". ${ }^{64}$ Finally, as previously mentioned, although serious human rights violations and crimes against humanity are closely connected, they are not identical. This idea arguably underlies the following statement by the late ICC Judge Hans-Peter Kaul: "It is neither appropriate nor possible to examine and explain in this opinion all the potential negative implications and risks of a gradual downscaling of crimes against humanity towards serious ordinary crimes". ${ }^{65}$

\section{Regional Human Rights COURTS (PARTICULARLY THE INTER-AmericAn COURT OF HUMAN RightS) AND INTERNATIONAL CRIMINAL COURTS ${ }^{66}$}

The relationship between the notion of serious human rights violations and the legal definition of crimes against humanity may be illustrated through case-law cross-referencing practice of, on the one hand, the IACtHR and, on the other hand, the ICTY and the Special Court for Sierra Leone (SCSL). These courts have mutually referred to and/or cited each other when ful-

63 Prosecutor v. Lubanga, ICC-01/04-01/06-3129, Judgment on the appeals against the "Decision establishing the principles and procedures to be applied to reparations" of 7 August 2012 with AMENDED order for reparations (Annex A) and public annexes 1 and 2, Appeals Chamber, 3 March 2015, paras. 127, 128 and 154.

64 Ibidem, para. 166.

65 Situation in the Republic of Kenya, ICC-01/09-19, Decision Pursuant to Article 15 of the Rome Statute on the Authorization of an Investigation into the Situation in the Republic of Kenya, Pre-Trial Chamber II, 31 March 2010, para. 10.

66 Additionally, see also: Pérez-León Acevedo, Juan Pablo, "International Criminal Law Sources in the Jurisprudence of the Inter-American Court of Human Rights. Some Comparative Considerations", in Centre for Human Rights of Nuremberg on-line papers, December 2008, available at: http://www.menschenrechte.org/wp-content/uploads/2009/12/Inter_am_syst_paper. pdf(last visited 9 September 2016). 
Esta revista forma parte del acervo de la Biblioteca Jurídica Virtual del Instituto de Investigaciones Jurídicas de la UNAM

filling their respective mandates, i.e., determination of international state responsibility for (serious) human rights violations at the IACtHR and determination of individual criminal responsibility for crimes against humanity at the ICTY/SCSL.

\section{IACtHR's Case-Law on Serious Human Rights Violations Invoked by International Criminal Justice Institutions}

The ICTY Trial Chamber, for example, made explicit references to Velasquez Rodriguez v. Honduras in its judgment in Prosecutor v. Kupreskic, ${ }^{67}$ to interpret and indeed give content to the loose clause of "other inhumane acts", one of the underlying crimes against humanity under article 5 .i of the ICTY Statute. Thus, the IACtHR's case-law on serious human rights violations influenced the ICTY's case-law on this particular crime against humanity. Therefore, the impact of the IACtHR's case law on this regard has gone beyond the regional system of human rights protection in the Americas.

The SCSL, a hybrid criminal court that had mandate to prosecute international crimes committed during the bloody armed conflict in Sierra Leone also made reference to the IAtCHR's jurisprudence. Accordingly, when evaluating the legality of amnesties for perpetrators of war crimes and crimes against humanity granted via the so-called Lomé agreement, the SCSL Appeals Chamber in Prosecutor v. Moinina Fofana and Allieu Kondewa referred to or cited diverse legal sources including cases at the Inter-American Commission of Human Rights (IACmHR). These cases concerned the Salvadorian non-international armed conflict. ${ }^{68}$ As to the IACtHR's caselaw, Barrios Altos v. Peru ${ }^{69}$ was mentioned to illustrate the international law trend in ruling out or prohibiting (self) amnesty laws that seek to shield those responsible for international crimes, crimes against humanity included, from individual criminal responsibility. ${ }^{70}$

67 Prosecutor v. Kupreškić et al., IT-95-16, Sentencing Judgment, Trial Chamber, 14 January 2000, paras. 563-566.

68 Prosecutor v. Moinina Fofana and Allieu Kondewa, SCSL-04-14-T-128-7347, SCSL04-14-T-128-7363, Decision on lack of jurisdiction / abuse of process: amnesty provided by the Lomé Accord, Appeals Chamber, 25 May 2004, paras. 36-38.

69 IACtHR, Barrios Altos v. Peru, Ser. C No. 75, Merits Judgment, 14 March 2001.

70 Prosecutor v. Moinina Fofana and Allieu Kondewa, SCSL-04-14-T-128-7347, SCSL- 
Esta revista forma parte del acervo de la Biblioteca Jurídica Virtual del Instituto de Investigaciones Jurídicas de la UNAM

Finally, the IACtHR's robust case-law on reparations for victims of serious human rights violations constitutive of crimes against humanity and other international crimes has been closely considered by the $\mathrm{ICC}^{71}$ and $\mathrm{ECCC}^{72}$ in their emerging case-law on reparations for victims of international crimes. This has included principles, forms, modalities and implementation of reparations for victims of international crimes.

However, attention must be paid not to automatically extrapolate the jurisprudential criteria from the IACtHR (and other human rights courts) to international/hybrid criminal courts and vice-versa considering the different mandates and functions of each type of judicial institution.

\section{Case-Law of International Criminal Justice Institutions Invoked by the IACtHR}

In turn, the influence of the ICTY's case-law on that of the IACtHR may be tracked down. For instance, in Almonacid-Arellano et al. v. Chile, the IACtHR stated that a single act of murder committed as part of a widespread or systematic attack against civilians is sufficient for the configuration of a crime against humanity. ${ }^{73}$ In reaching this conclusion, the IACtHR referred to the reasoning of the ICTY in, inter alia, Prosecutor v. Tadic. ${ }^{74}$ In the same judgment, the IACtHR justified its conclusion of the prohibition of crimes against humanity and constitutive elements as part of customary public international law, ${ }^{75}$ based upon the findings of the International Military

04-14-T-128-7363, Decision on lack of jurisdiction / abuse of process: amnesty provided by the Lomé Accord, Appeals Chamber, 25 May 2004, para. 44.

71 Prosecutor v. Lubanga, ICC-01/04-01/06-3129, Judgment on the appeals against the "Decision establishing the principles and procedures to be applied to reparations" of 7 August 2012, Order for Reparations, Appeals Chamber, 3 March 2015; Prosecutor v. Lubanga, ICC01/04-01/06-2904, Decision establishing the principles and procedures to be applied to reparations, Trial Chamber, 7 August 2012.

72 E.g., Case 002/01, Judgment, Trial Chamber, 7 August 2014.

73 IACtHR, Almonacid-Arellano et al. v. Chile, Ser. C No. 154, Preliminary Objections, Merits, Reparations and Costs, Judgment, 26 September 2006, para. 96.

74 Prosecutor v. Dusko Tadic, IT-94-1-T, Opinion and Judgment, Trial Chamber, 7 May 1997, para. 649. This was subsequently confirmed by the ICTY in Prosecutor v. Kupreskic et al., IT-95-16-T, Trial Chamber, Judgment, 14 January 2000, para. 550; and Prosecutor v. Kordic \& Cerkez, IT-95-14/2-T, Judgment, Trial Chamber, 26 February 2001, para. 178.

75 IACtHR, Almonacid-Arellano et al. v. Chile, Ser. C No. 154, Preliminary Objections, Mer- 
Esta revista forma parte del acervo de la Biblioteca Jurídica Virtual del Instituto de Investigaciones Jurídicas de la UNAM

Tribunal of Nuremberg. ${ }^{76}$ Finally, as part of its legal arguments to deny amnesty for crimes against humanity, the IACtHR made reference to the judgment in Prosecutor v. Erdemovic rendered by the ICTY Trial Chamber. ${ }^{77}$ In Massacre of El Mozote and Nearby Places v. El Salvador, the IACtHR referred to, inter alia, a number of judgements of the ICTY, ICTR and the SCSL to reaffirm that amnesty laws are inapplicable to international crimes committed in internal armed conflicts. ${ }^{78}$

In Myrna Mack- Chang v. Guatemala ${ }^{79}$ and Plan de Sánchez v. Guatemala, ${ }^{80}$ international crimes were masterminded and executed according to a plan that stemmed from the highest governmental echelons. Thus, state authorities used the state apparatus to perpetrate international crimes as well as to deny the facts, block victims' access to rights to justice and the truth, all of which caused aggravated responsibility as these were serious breaches of obligations under international law peremptory norms. ${ }^{81}$

The IACtHR's findings relying on international criminal law sources, including jurisprudence of international criminal courts and tribunals, are quite important as international crimes have been committed across LatinAmerica both during peace time and armed conflicts. Thus, for example, in Almonacid-Arellano v. Chile, the extra-judicial execution of Mr. AlmonacidArellano was examined by the IACtHR as a crime against humanity inso-

its, Reparations and Costs, Judgment, 26 September 2006, para. 97. The ECtHR in Kolk and Kislyiy v. Estonia followed the same approach. See Kolk and Kislyiy v. Estonia, Apps. No. 23052/04 and No. 24018/04, Judgment, 17 January 2006.

76 France et al. v. Goering et al., International Military Tribunal for the trial of the Major War Criminals of Nuremberg, Judgment, Sep. 30-Oct. 1 1946, at 218.

77 Prosecutor v. Erdemovic, IT-96-22-T, Sentencing Judgment, Trial Chamber, 29 November 1996, para. 28.

78 IACtHR, Massacre of El Mozote and Nearby Places v. El Salvador, Judgment, 25 October 2012, paras. 283-296.

79 IACtHR, Myrna Mack-Chang v. Guatemala, Ser. C No. 101, Merits, Reparations and Costs, Judgment, 25 November 2003.

80 IACtHR, Plan de Sánchez Massacre v. Guatemala, Ser. C No. 105, Merits, Judgment, 29 April 2004.

81 See International Law Commission, Report of the International Law Commission on the work of its Fifty-Third Session, May 6-July 26, 2001, U.N.GAOR, 53 th Sess., Supp. No. 10, U.N. Doc. A/51/10 (2001). 2001 Draft articles on Responsibility of States for internationally wrongful acts adopted by the International Law Commission at its fifty-third session, part II, chapter III, articles 40 and 41 . 
far as that arbitrary deprivation of life took place within a widespread and systematic pattern of serious human rights violations perpetrated against civilian population by state agents during the late ex-President Pinochet's dictatorship. ${ }^{82}$ In assessing the evidence filed, the IACtHR concluded that the first stages of Pinochet's dictatorial regime registered the highest percentage of death and forced disappearances of persons. ${ }^{83}$ Based upon caselaw of international criminal courts and other international criminal law sources which fleshed out the objective and subjective elements of crimes against humanity, ${ }^{84}$ the IACtHR found that:

...the commission of crimes against humanity, including murder committed in the course of a generalized or systematic attack against certain sectors of the civil population, was in violation of a binding rule of international law. Said prohibition to commit crimes against humanity is a ius cogens rule, and the punishment of such crimes is obligatory pursuant to the general principles of international law. ${ }^{85}$

Like other human rights bodies and courts, the IACtHR lacks jurisdiction to determine international state responsibility for treaties which are outside its mandate, e.g., the 1949 Geneva Conventions or the Convention on the Prevention and Punishment of the Crime of Genocide. Nor does the IACtHR hold jurisdiction to determine individual criminal liability for crimes against humanity unlike the ICC or other international and hybrid criminal tribunals. However, the lack of subject-matter or ratione materiae competence does not exempt the State from international responsibility for serious human rights violations of the American Convention on Human Rights and/or other inter-American human rights treaties. ${ }^{86}$ As the former President of the IACtHR and current International Court of Justice Judge

82 IACtHR, Almonacid-Arellano et al. v. Chile, Ser. C No. 154, Preliminary Objections, Merits, Reparations and Costs, Judgment, 26 September 2006, para. 104.

83 Ibidem, para. 103.

84 Ibidem, paras. 94-104.

85 Ibidem, para. 99.

86 IACtHR, Plan de Sánchez Massacre v. Guatemala, Ser. C No. 105, Merits, JudgmentSeparate Opinion of Judge Antonio A. Cançado-Trindade, 29 April 2004, para. 7. See also Cançado-Trindade, Antonio, The Access of Individuals to International Justice, Oxford, Oxford University Press, 2011. 
Cançado-Trindade noted, there is an underlying principle of humanity. ${ }^{87}$ Thus, the universal condemnation of serious human rights violations constitutive of international crimes, including crimes against humanity, had already been part of:

...the human conscience a long time before they were typified or codified at the international level, either in the 1948 Convention on the Prevention and Punishment of Genocide, or in other human rights or international humanitarian law treaties. Nowadays, international crimes are condemned by both general and treaty-based international law. ${ }^{88}$

In Manuel CepedaVargas v. Colombia, the IACtHR further fleshed out and clarified the relationship between serious human rights violations and crimes against humanity and how this fits into the IACtHR's mandate. The IACtHR made it clear in Manuel Cepeda Vargas v. Colombia that it does not establish individual responsibility, which corresponds to the jurisdiction of domestic or international criminal courts. ${ }^{89}$ Conversely, the IACtHR's mandate is limited to assess the facts submitted in accordance with the American Convention on Human Rights and other treaties that grant the IACtHR's jurisdiction and to apply these instruments over which it has jurisdiction..$^{90}$ Be that as it may, like in previous cases of serious human rights violations, in Manuel Cepeda Vargas v. Colombia, the IACtHR considered whether those violations were perpetrated as part of massive and systematic or generalized attacks against one sector of the population, i.e., whether it would be possible to characterize them as crimes against humanity. ${ }^{91}$ Even though the IACtHR has no competence to determine individual criminal responsibility:

...the need for comprehensive protection of the individual under the Convention has led the Court to interpret its provisions through their convergence with other norms of international law, particularly with regard to the prohibition of crimes

87 IACtHR, Plan de Sánchez Massacre v. Guatemala, Ser. C No. 105, Merits, Judgment- Separate Opinion of Judge Antonio A. Cançado-Trindade, 29 April 2004, paras. 9-10.

88 Ibidem, para. 13.

89 IACtHR, Manuel Cepeda Vargas v. Colombia, Ser. C No. 103, Preliminary objections, merits, reparations and Costs, Judgment, 26 May 2010, para. 41.

90 Ibidem.

91 Ibidem, para. 42 
against humanity, which is ius cogens, without this implying that it has exceeded its powers, because, it should be reiterated that, in doing so, it respects the authority of the criminal jurisdiction to investigate, indict and punish the individuals responsible for such crimes. What the Court does, in accordance with treaty-based law and customary law, is to employ the terminology used by other branches of international law in order to assess the legal consequences of the alleged violations vis-à-vis the State's obligations. ${ }^{92}$

Therefore, the IACtHR in Manuel Cepeda Vargas v. Colombia declared the third preliminary objection filed by Colombia inadmissible as this held no relation to the extent of the IACtHR's competence due to the fact that the IACtHR "would never charge a natural person or a State with the perpetration of a crime". ${ }^{93}$ Concerning this last statement, the following caveat should be enunciated. As the IACtHR states, it is true that a State cannot be "charged" with the commission of an international crime; however, it is observed here that a State can be found international responsible, i.e., international state responsibility of a civil-like nature rather than criminal individual liability, for the commission of an international crime. For example, Bosnia-Herzegovina litigated a case against Serbia and Montenegro for violations of the Convention against Genocide before the International Court of Justice. ${ }^{94}$ Additionally, a former President of the IACtHR, Judge Antonio CancadoTrindade, has referred to an aggravated international state responsibility triggered by the commission of international crimes. ${ }^{95}$

\section{Overall Assessment}

Based upon the practice of international and regional courts regarding the relationship between the notion of serious human rights violations and the legal

92 Ibidem.

93 Ibidem, para. 43.

94 International Court of Justice, Application of the Convention on the Prevention and Punishment of the Crime of Genocide (Bosnia and Herzegovina v. Serbia and Montenegro), Judgment, 26 February 2007.

95 IACtHR, Servellón García et al. v. Honduras, Ser. C No. 152, Merits, Reparations and Costs, Judgment-Concurring Vote of Judge Cançado Trindade, 21 September 2006, paras. $2-10$. 
definition of crimes against humanity examined in the previous sub-sections, the following may be concluded. First, the IACtHR has arguably been among all international courts the institution which has explicitly and in most detail fleshed out the relationship between the notion of serious human rights violations and the legal definition of crimes against humanity. One of the reasons underlying this is that the IACtHR's judgments must produce effects at the national level. Particularly, the non-application of amnesties and statute of limitations as determined by the IACtHR's judgments takes place in national criminal proceedings. If it is recalled that qualification of some acts as crimes against humanity reinforces and justifies those national legal effects, it may be better understood the trend of the IACtHR's jurisprudence whereby there is a qualification of serious human rights violations as crimes against humanity. This corresponds to the fact that, as seen in the next section, the legal consequences of labelling a particular serious human rights violation as a crime against humanity involve removing procedural and substantive law obstacles which may arise at national level.

Second, when it comes to the practice of international and hybrid criminal courts, particularly the ICC, there has not been quite a detailed analysis of the relationship between the two categories under consideration. This is explained by the fact that these international and hybrid criminal courts apply instruments which are primarily limited to specific cases before them. In other words, the facts and events of particular cases before the ICC and the other international and hybrid criminal courts just need to be examined in the light of the respective statutory definitions of crimes against humanity. Nevertheless, as evidenced in the last two sections, the ICC and other international criminal justice fora have normally examined the framework of serious human rights violations within which a legal qualification of some of the events corresponds to crimes against humanity. Be that as it may, it could be interesting if the Judges of the ICC, as the only permanent international criminal court, in further detail address the relationship between the notion of serious human rights violations and the legal definition of crimes against humanity. 
Esta revista forma parte del acervo de la Biblioteca Jurídica Virtual del Instituto de Investigaciones Jurídicas de la UNAM

\section{Legal Consequences of the Qualification of Serious Human RigHTS ViOlations as CRimes A gainst HUMANITY}

\section{Exercise of universal jurisdiction}

A general consequence of the qualification of serious human rights violations as crimes against humanity is the international state obligation to sanction those individuals responsible for crimes against humanity regardless of who committed them, against whom and where those crimes were perpetrated, i.e., via the exercise of universal jurisdiction. ${ }^{96}$ Thus, when it comes to international crimes such as crimes against humanity, any national criminal court may exercise jurisdiction without the presence of traditional jurisdictional links. Accordingly, there is no need that the crime was perpetrated by a national of the State considering to exercise jurisdiction (active personality link) or that the crime was committed in the territory of the State seeking to exercise jurisdiction (territorial link) or against a national of the State considering to exercise jurisdiction (passive personality link) ${ }^{97}$

Concerning treaty basis for the exercise of universal jurisdiction, there is no international multilateral treaty on crimes against humanity and, therefore, there is in principle no treaty basis for the exercise of this type of jurisdiction over crimes against humanity. Nevertheless, the immense majority of States members of the international community are States parties to international and/or regional treaties dealing with specific underlying criminal conducts constitutive of crimes against humanity. In particular, regional and/or international treaties against torture, forced disappearance and apartheid include the principle aut dedere aut iudicare and, thus, those States have the obligation to either try or extradite suspects of those serious offences. Should a State decide to proceed with the prosecution, it does not matter the traditional jurisdictional links, i.e., territorial and personality links. In other words, these treaties enable national courts to exercise universal jurisdiction over underlying crimes constitutive of crimes against

96 See, for detailed discussion on universal jurisdiction, inter alia, Sands, Philippe, "After Pinochet: The role of national courts", in Sands, Philippe (ed.), From Nuremberg to The Hague. The Future of International Criminal Justice, Cambridge, Cambridge University Press, 2003, pp. 68-108.

97 See Cassese, op. cit., pp. 278-300. 
Esta revista forma parte del acervo de la Biblioteca Jurídica Virtual del Instituto de Investigaciones Jurídicas de la UNAM

humanity. The UN Convention against Apartheid provides for a go-ahead for universal jurisdiction. ${ }^{98}$ In turn, the UN Convention against Torture lays down that:

2. Each State Party shall likewise take such measures as may be necessary to establish its jurisdiction over such offences in cases where the alleged offender is present in any territory under its jurisdiction and it does not extradite him...

3. This Convention does not exclude any criminal jurisdiction exercised in accordance with internal law [emphasis added]. ${ }^{99}$

Using quite a similar wording, the UN Convention against Enforced Disappearance of Persons also enables the exercise of universal jurisdiction. ${ }^{100}$ Therefore, it is argued herein that should one single act of an underlying conduct constitutive of crimes against humanity such as torture or enforced disappearance of persons trigger universal jurisdiction, the commission of the same underlying conducts in a widespread or systematic manner, i.e., crimes against humanity, a fortiori must enable national courts to exercise universal jurisdiction.

As for the underlying criminal conducts constitutive of crimes against humanity which are not regulated by treaties that explicitly provide for universal jurisdiction and also for crimes against humanity in general, the existence of customary law or general principles of law may be invoked. Thus, under these two other international law sources, it is possible to

98 International Convention on the Suppression and Punishment of the Crime of Apartheid, 30 November 1973, article V ("Persons charged with the acts enumerated in article II of the present Convention may be tried by a competent tribunal of any State Party to the Convention which may acquire jurisdiction over the person of the accused or by an international penal tribunal having jurisdiction with respect to those States Parties which shall have accepted its jurisdiction”).

99 Convention against Torture and Other Cruel, Inhuman or Degrading Treatment or Punishment, 10 December 1984, article 5.

100 International Convention for the Protection of All Persons from Enforced Disappearance, 20 December 2006, articles 9.2 and 9.3. ("2. Each State Party shall likewise take such measures as may be necessary to establish its competence to exercise jurisdiction over the offence of enforced disappearance when the alleged offender is present in any territory under its jurisdiction, unless it extradites or surrenders him or her to another State. 3. This Convention does not exclude any additional criminal jurisdiction exercised in accordance with national law [emphasis added]). 
Esta revista forma parte del acervo de la Biblioteca Jurídica Virtual del Instituto de Investigaciones Jurídicas de la UNAM

argue that national courts can exercise universal jurisdiction over crimes against humanity and/or that national courts are obliged to exercise universal jurisdiction over those serious offences if they decide not to extradite the alleged offenders. Some specific examples of national and international practice supporting this last point are presented as follows.

There is indeed important practice which evidences the exercise of universal jurisdiction over serious human rights violations which constituted crimes against humanity. Thus, state legislation has granted jurisdiction to national courts over acts constitutive of crimes against humanity. ${ }^{101}$ For example, as a consequence of the crimes perpetrated in the formerYugoslavia and Rwanda, criminal prosecution against Bosnian and Rwandan nationals respectively was put in motion in France and Switzerland. ${ }^{102}$

Another example of universal jurisdiction exercise consisted in the extradition case concerning Pinochet before the former House of Lords, which was related to acts involving systematic and generalized practice of serious human rights violations, particularly, torture, extrajudicial killings and enforced disappearance. Lord Millet concluded that international crimes, including crimes against humanity, are subject to the exercise of universal jurisdiction and, therefore, the United Kingdom could exercise jurisdiction over crimes against humanity perpetrated by non-British nationals (against non-British victims) and outside British soil: "the systematic use of torture on a large scale and as an instrument of state policy had joined piracy, war crimes and crimes against peace as an international crime of universal jurisdiction well before 1984". ${ }^{103}$

Additionally, the ICTY in Furundzija, examining torture committed in a systematic pattern, i.e., as a crime against humanity, concluded that the legal foundation for "State's universal jurisdiction over torture bears out and strengthens the legal foundation for such jurisdiction found by other courts

101 E.g., Canadian Criminal Code (as amended by the Act C-71 (1987), section 7.3.71) and Israeli legislation (1950), article 1.a, concerning sanction of Nazis and their collaborators.

102 For detail references see Lekha, Sandra, "Revolutions in Accountability: New Approaches to Past Abuses", American University International Law Review, vol. 19, n. 2, 2003, pp. 343 et seq.

103 House of Lords (United Kingdom), Regina v. Bow Street Metropolitan Stipendiary Magistrate and Others, ex parte Pinochet Ugarte, Judgment, 24 March 1999, Opinion of Lord Millet. 
Esta revista forma parte del acervo de la Biblioteca Jurídica Virtual del Instituto de Investigaciones Jurídicas de la UNAM

in the inherently universal character of the crime". ${ }^{104}$ Due to the universal condemnation of international crimes and wherever they take place, "every State has the right to prosecute and punish the authors of such crimes". ${ }^{105}$

\section{Non-applicability of statute of limitations}

With regard to the non-applicability of statute of limitations to crimes against humanity and, thus, serious human rights violations, the UN Convention on the Non-Applicability of Statutory Limitations to War Crimes and Crimes Against Humanity is of great importance as this international instrument lays down that these crimes can be prosecuted no matter when they were perpetrated. ${ }^{106}$ Additionally, the UN Convention on the Non-Applicability of Statutory Limitations includes a specific provision on several manifestations of modes of individual criminal responsibility for both war crimes and crimes against humanity. ${ }^{107}$ Furthermore, the 1974 European Convention on the Non-Applicability of Statutory Limitations to Crimes against Humanity and War Crimes also evidences a trend in non-applicability of statutory limitations in case of international crimes. ${ }^{108}$ An explicit provision on non-applicability of statutory limitations is also incorporated in the ICC Statute: "The crimes within the jurisdiction of the Court shall not be subject to any statute of limitations". ${ }^{109}$ However, the ICC has temporal competence over crimes perpetrated after the entry into force of the ICC Statute: "The Court has jurisdiction only with respect to crimes committed after the entry into force of this Statute". ${ }^{110}$ Among hybrid criminal tribunals, the UNTAET Regulation No. 2000/15 for East Timor provides for no statute of limitation as for inter alia crimes against humanity. ${ }^{111}$

104 Prosecutor v. Furundžija, IT-95-17/1, Sentencing Judgment, Trial Chamber, 10 December 1998, para. 155.

105 Idem.

106 Convention on the Non-Applicability of Statutory Limitations to War Crimes and Crimes Against Humanity, 26 November 1968, article I.

107 Convention on the Non-Applicability of Statutory Limitations to War Crimes and Crimes Against Humanity, article II.

108 It should however be considered that only three states have ratified this treaty.

109 ICC Statute, article 29. Non-applicability of statute of limitations.

110 ICC Statute, article 11.1. Jurisdiction ratione temporis.

111 UNTAET Regulation No. 2000/15 for East Timor, section 17. 
Esta revista forma parte del acervo de la Biblioteca Jurídica Virtual del Instituto de Investigaciones Jurídicas de la UNAM

International monitoring human rights bodies have agreed on the primacy of the principle of non-applicability of statute of limitations to serious human rights violations constitutive of crimes against humanity over the principle of non-retroactivity in order to fight impunity. The ECtHR in Cestaro v. Italy found that cases of torture or ill-treatment perpetrated by state agents "ought not to be discontinued on account of a limitation period". ${ }^{112}$ The IACmHR concluded that although the non-retroactive application of the law is a general principle, concerning serious human rights violations it "cannot be invoked with respect to those granted amnesty because at the time the acts in question were committed they were classified and punishable under Chilean law in force". ${ }^{113}$ In turn, the Human Rights Committee, concerning Argentina, concluded that, in order to bring those responsible to justice, serious human rights violations “... should be prosecutable for as long as necessary, with applicability as far back in time as necessary to bring their perpetrators to justice". ${ }^{114}$

At the national level, French courts found non-applicability of statutes of limitations concerning crimes against humanity in connection with Second World War events. In Barbie, the French Court of Cassation rendered its judgment based upon a two-pronged basis. Firstly, the non-applicability of statute of limitations concerning crimes against humanity is a principle which stems from the Statute of the International Military Tribunal of Nüremberg, and, secondly, the right to statute of limitations falls short of those human rights protected under French legislation. ${ }^{115}$ However, the Court found that there was no general customary international rule excluding the application of statutes of limitations as for war crimes. Nevertheless, much more recently, the International Committee of the Red Cross (ICRC) has actually showed the existence of such customary international humanitarian law

112 ECtHR, Cestaro v. Italy, application no. 6884/11, 7 April 2015, para. 208.

113 IACmHR, Carmelo Soria Espinoza (Chile), Report No. 133/99, Case 11.725, 19 November 1999, para. 76. For further discussion, see Andreu-Guzmán, Federico, "Imprescriptibilidad de los crímenes de lesa humanidad versus irretroactividad de la ley penal: un falso dilema", in: Coordinadora Nacional de Derechos Humanos, Retos de la Judicialización. En el proceso de verdad, justicia, reparación y reconciliación, Lima, 2005, pp. 151-157.

114 Concluding observations of the Human Rights Committee: Argentina, 11 March 2000, CCPR/CO/70/ARG. (Concluding Observations/Comments) para. 9.

115 Court of Cassation of France, Criminal Chamber, Case Klaus Barbie, Judgment, 20 January 1984, pp. 314 et al. 
rule. ${ }^{116}$ In any event, in Touvier, the French Court of Cassation concluded that there was no accused person's right to the application of statute of limitations in cases of crimes against humanity. ${ }^{117}$

Therefore, there is arguably consensus on the non-applicability of statute of limitations to serious human rights violations constitutive of crimes against humanity. ${ }^{118}$

\section{Non-applicability of Amnesty Laws}

An important legal consequence of the qualification of serious human rights violations as crimes against humanity is their exclusion from the scope of application of amnesty laws. Precisely, in the practice of the IACmHR, there are several cases stemming from amnesty laws passed by diverse LatinAmerican dictatorships which existed in the region in previous decades.

Self-amnesty laws were rendered in inter alia Argentina, Brazil, Chile, Peru, Uruguay, and Central-America. Although these laws have different denominations and different scopes of material and/or temporal application, they share in common their adoption as a mechanism to shield individuals from criminal responsibility and other types of liabilities for crimes against humanity. ${ }^{119}$ Due to length restrictions, the Peruvian case is considered herein to illustrate the features of these laws. During the former President Alberto Fujimori's first term, on 14 June 1995, the Peruvian Parliament, mainly constituted by Fujimori's political party members, passed Act No. 26479. Its first article granted a general amnesty in favor of all those armed forces members and civilians who were denounced, investigated, o condemned for human rights violations between May 1980 and 15 June 1995. As a judge did not apply this first self-amnesty law, on 28 June 1995, the Parliament passed a second Act to enhance the effects of the first Act. Thus, two new effects were brought about: i) the judiciary was prevented

116 ICRC, Customary International Humanitarian Law Rules, rule 160.

117 Court of Cassation of France, Criminal Chamber, Case Touvier, Judgment, 27 November 1992.

118 Abellán, Victoria, op. cit., p. 386.

119 See further Norris, Robert, "Leyes de Impunidad y los Derechos Humanos en las Américas: Una Respuesta Legal”, Revista del Instituto Interamericano de Derechos Humanos, vol. 15, 1992, pp. 47-110. 
from deciding on the legality or application of the first amnesty law; and ii) the scope of the amnesties was expanded by granting a general amnesty to military, police or civilian personnel subject to denunciation for human rights violations.

Generally speaking, Latin-American amnesty laws had a two pronged effect. On the one hand, military and political superiors and/or commanders were exonerated from criminal investigation and prosecution. On the other one, subordinates were allowed to successfully invoke criminal defences such as duress and obedience to superior orders. The outcome was that victims of crimes against humanity/serious human rights violations and their lawyers could not find justice at the domestic level. This explains the large number of cases litigated in the Inter-American system for many years and which are related, directly or indirectly, to this serious obstruction of justice. This severely affected both retributive justice mechanisms, i.e., criminal sanction for the perpetrators, and restorative justice, i.e., reparations for victims. All of this has made transitional justice processes lengthy and difficult in the region.

International norms on individual criminal responsibility for crimes against humanity enhance the general international principle of respect for human rights as they limit the state discretional power and, thus, introduce prohibitions to granting amnesty to those responsible for serious human rights violations. ${ }^{120}$ In turn, an individual who is a perpetrator of serious human rights violations, constitutive of crimes against humanity, is responsible under international law, letting alone the responsibility that may be attributed under domestic law.

The passing of amnesty laws to exonerate perpetrators of serious human rights violations constitutive of crimes against humanity from individual criminal responsibility has also been examined at the IACtHR. Accordingly, the IACtHR in the seminal Barrios Altos v. Peru stated that amnesty laws adopted by the Peruvian State to exonerate perpetrators of widespread or systematic practices of torture, extrajudicial killings or forced disappearance of persons from responsibility were incompatible with the international protection of hard core human rights: 
This Court considers that all amnesty provisions, provisions on prescription and the establishment of measures designed to eliminate responsibility are inadmissible, because they are intended to prevent the investigation and punishment of those responsible for serious human rights violations such as torture, extrajudicial, summary or arbitrary execution and forced disappearance, all of them prohibited because they violate non-derogable rights recognized by international human rights law. ${ }^{121}$

As a result of the IACtHR judgment in Barrios Altos v. Peru, the above-referred Peruvian self-amnesty laws lack legal effects and, therefore, they have no longer impinged the determination of individual criminal responsibility in any serious human rights violation case in Peru, i.e., a general effect finding:

Owing to the manifest incompatibility of self-amnesty laws and the American Convention on Human Rights, the said laws lack legal effect and may not continue to obstruct the investigation of the grounds on which this case is based or the identification and punishment of those responsible, nor can they have the same or a similar impact with regard to other cases that have occurred in Peru, where the rights established in the American Convention have been violated. ${ }^{122}$

The IACtHR has declared other amnesty laws passed by authoritarian/dictatorial regimes void and lacking effects in more recent case-law. Thus, in Almonacid-Arellano et al. v. Chile, as a result of considering the murder of Mr. Almonacid-Arellano as a crime against humanity, the IACtHR concluded that the Chilean amnesty law could not be applicable:

...there is sufficient evidence to reasonably state that the extra-legal execution committed by State agents... was committed following a systematic and generalized pattern against the civilian population, and thus, it is a crime against humanity. ...the States cannot neglect their duty to investigate, identify, and punish those persons responsible for crimes against humanity by enforcing amnesty laws or

121 IACtHR, Barrios Altos v. Peru, Ser. C No. 75, Merits Judgment, 14 March 2001, para. 41.

122 IACtHR, Barrios Altos v. Peru, Ser. C No. 75, Merits Judgment, 14 March 2001, para. 44. See also IACtHR, Barrios Altos v. Peru, Ser. C No. 83, Interpretation of the Judgment of the Merits. Judgment, 3 September 2001. 
Esta revista forma parte del acervo de la Biblioteca Jurídica Virtual del Instituto de Investigaciones Jurídicas de la UNAM

any other similar domestic provisions. Consequently, crimes against humanity are crimes which cannot be susceptible of amnesty. ${ }^{123}$

More recently, in Gomez Lund et al. v. Brazil, the IACtHR once again put aside amnesty laws, in this case, in the Brazilian context, as the Court found that a Brazilian amnesty law impeded the investigation and punishment of serious human rights violations and, as a consequence, the said amnesty law should lack legal effects. ${ }^{124}$ In Gelman vs. Uruguay, the IACtHR put aside an amnesty law albeit it had been approved by a national referendum. ${ }^{125}$

The ECtHR in relatively recent case-law has also found that amnesty laws cannot apply to serious human rights violations and, thus, potentially constitutive of international crimes, including crimes against humanity. Thus, the Grand Chamber of the ECtHR in Marguš v. Croatia found that: "The possibility for a State to grant an amnesty in respect of grave breaches of human rights may be circumscribed by treaties to which the State is a party. There are several international conventions that provide for a duty to prosecute crimes defined therein...". ${ }^{126}$ Also, in Cestaro v. Italy, the ECtHR found that "amnesties and pardons should not be tolerated" in cases of torture or ill-treatment perpetrated by state agents. ${ }^{127}$

At the domestic level, inter alia, national courts in Latin-America have internally embraced the IACtHR's above-examined findings. For instance, the Constitutional Tribunal of Peru and the Supreme Court of Argentina. ${ }^{128}$ The former pointed out the $a b$ initio lack of effects of the Peruvian amnesty laws as determined by the IACtHR. The Argentinian Supreme Court based on, especially, findings in the IACtHR's Barrios Altos v. Peru judgment, found the laws of final stop and due obedience (Argentinian amnesty laws) un-

123 IACtHR, Almonacid-Arellano et al. v. Chile, Ser. C No. 154, Preliminary Objections, Merits, Reparations and Costs, Judgment, 26 September 2006, paras. 104 y 114.

124 IACtHR, Gomes Lund et al. (“Guerrilha do Araguaia”) v. Brazil, Ser. C No. 219, Preliminary Objections, Merits, Reparations, and Costs, 24 November 2010, para. 174.

125 IACtHR, Gelman vs. Uruguay, Ser. C No. 221, Merits and Reparations, 24 February 2011 .

126 ECtHR, Marguš v. Croatia, application no. 4455/10, 27 May 2014, para. 132.

127 ECtHR, Cestaro v. Italy, application no. 6884/11, 7 April 2015, para. 208.

128 Constitutional Tribunal of Peru, File $N^{\circ}$ 679-2005-PA/TC, 2 March 2007, paras. 3560; Supreme Court of Argentina, Judgment 1767-XXVIII. Simón, Julio Héctor et al., $\mathrm{N}^{\circ}$ $17.768,14$ June 2005 . 
constitutional. It concluded that the Argentinian amnesty laws presented the same flaws, i. e., obstruction of justice, that prompted the IACtHR to declare null and void the Peruvian self-amnesty laws.

\section{CONCLUSIONS}

Two main conclusions which address the research questions and verify the hypotheses presented in the introduction can be presented herein. First, there is indeed a relationship between the notion of serious human rights violations and the legal concept of crimes against humanity. Under international law, this relationship is of a close and intrinsic nature although those two categories remain autonomous from each other. The overall balance of differences and similarities between them point to their being intertwined. Second, the relationship between serious human rights violations and crimes against humanity is manifested in two mutually complementary ways. On the one hand, serious human rights violations may be and have been criminalized as crimes against humanity and, therefore, are constitutive of this category of international crimes. On the other hand, crimes against humanity constitute a very important manifestation of serious human rights violations in the field of international criminal law.

Accordingly, there is an intense relationship between serious violations of human rights, particularly those affecting hard core human rights, and crimes against humanity. Diverse nature sources of international law have increasingly and more often highlighted this relationship. A general rule on individual criminal responsibility for serious human rights violations has emerged since individual criminal responsibility has been sufficiently implemented. ${ }^{129}$

Particularly, this implementation has been undertaken by the establishment of a wide array of international and hybrid criminal courts with competence over crimes against humanity in the last twenty years, all of which has led to an ever-increasing case-law on the subject. This in turn has largely triggered the national incorporation of international provisions on crimes against humanity closely linked to criminal responsibility for serious human

129 Sunga, Lyal, op. cit., p. 157. 
Esta revista forma parte del acervo de la Biblioteca Jurídica Virtual del Instituto de Investigaciones Jurídicas de la UNAM

rights violations world-wide. In turn, by using international criminal law sources in interpreting human rights provisions concerning cases of serious human rights violations, case-law of regional human rights courts such as the IACtHR has also and importantly contributed to this trend.

\section{MiNIMAL BIBLIOGRAPHY*}

ABELlÁn, Victoria, "La responsabilité internationale de l'individu", Recueil des Cours de la Académie de Droit International, t. 280, 1999.

AmbOs, Kai, El nuevo derecho penal internacional, Lima, ARA Editores, 2004. ANDREU-GuZMÁn, Federico, "Imprescriptibilidad de los crímenes de lesa humanidad versus irretroactividad de la ley penal: un falso dilema", in Coordinadora Nacional de Derechos Humanos, Retos de la Judicialización. En el proceso de verdad, justicia, reparación y reconciliación, Lima, 2005.

CANÇADO-TRINDADE, Antonio, The Access of Individuals to International Justice, Oxford, Oxford University Press, 2011.

CARrillo Salcedo, Antonio, Soberanía de los Estados y derechos humanos en derecho internacional contemporáneo, 2a. ed., Madrid, Tecnos, 2001.

CASSESE, Antonio, International Criminal Law, 1st. ed., Oxford, Oxford University Press, 2003.

DuPuY, Pierre-Marie, Droit International Public, Paris, Dalloz, 1998.

LEKHA, Sandra, "Revolutions in Accountability: New Approaches to Past Abuses", American University International Law Review, vol. 19, n. 2, 2003. Meron, Theodor, "War Crimes Law Comes of Age", American Journal of International Law, vol. 92, n. 3, 1998.

-, "International Law in the Age of Human Rights-General Course on Public International Law", Recueil Générale de Cours de la Académie de Droit International, vol. 301, 2003.

NORRIS, Robert, "Leyes de Impunidad y los derechos humanos en las Américas: una respuesta legal", Revista del Instituto Interamericano de Derechos Humanos, vol. 15, 1992.

NOVAK, Fabián and SALMÓN, Elizabeth, Las obligaciones internacionales del Perú en materia de derechos humanos, Lima, Fondo Editorial de la Pontificia Universidad Católica del Perú-IDEI, 2002.

\footnotetext{
* NB: Concerning sources other than legal literature, e.g., case-law, see footnotes.
} 
PÉREZ-LEÓN, Juan, "International Criminal Law Sources in the Jurisprudence of the Inter-American Court of Human Rights. Some Comparative Considerations", in Centre for Human Rights of Nuremberg on-line papers, December 2008, at: http://www. menschenrechte.org/wp-content/up loads /2009/12/Inter_am_syst_paper.pdf (last visited 9 September 2016).

Remiro Brotóns, Antonio et al., Derecho internacional público, Madrid, Tecnos, 1997.

SADAT, Leila Nadya (ed.) Forging a Convention for Crimes against Humanity, Cambridge, Cambridge University Press, 2011.

SANDS, Philippe, "After Pinochet: The Role of National Courts", in SANDS, Philippe (ed.) From Nuremberg to The Hague. The Future of International Criminal Justice, Cambridge, Cambridge University Press, 2003.

Schabas, William, An Introduction to the International Criminal Court, 2nd. ed., Cambridge, Cambridge University Press, 2004.

, The International Criminal Court. A Commentary on the Rome Statute, Oxford, Oxford University Press, 2010.

Sunga, Lyal, Individual Responsibility in International Law for Serious Human Rights Violations, Amsterdam, Martinus Nijhoff, 1992. 